\title{
GOVERNMENT SIZE AND ECONOMIC GROWTH IN TURKEY: A THRESHOLD REGRESSION ANALYSIS
}

\section{Pelin Varol lyidogan, Taner Turan*}

\begin{abstract}
We examine the relationship between the government size and economic growth by using threshold regression model and quarterly data over the period 1998:1-2015:1 for Turkey. Our results provide a strong evidence for the existence of a non-linear relationship. The estimated threshold levels, as a percentage of GDP, are 16.5 for the government total expenditures, 12.6 for consumption expenditures and 3.9 for investment expenditures. We find that an increase in the government size leads to a significant rise (decline) in economic growth rate when the government size is below (above) the threshold level, confirming the predictions of Armey curve. Our findings have a clear policy implication: since the realized government consumption and total expenditures are well above the estimated threshold levels, a reduction in the government size would boost the growth rate.
\end{abstract}

Keywords: economic growth, government size, non-linearity, threshold estimations JEL Classification: E60, E62, H00, H50

\section{Introduction}

In neoclassical Solow (1956) model, a change in fiscal policy, such as an increase in government spending, has a level but not a growth effect in the long run. However, endogenous growth models, developed in the late 1980s and early 1990s, such as Barro (1990), Barro and Sala-i Martin (1992) and King and Rebelo (1990), suggest that the fiscal policy would be more effective in changing the growth rate. This implication has sparked a renewed interest in the investigation of the effect of fiscal policy on economic growth.

Government spending, as a share of GDP, has increased in many countries over time, thereby causing the possible effect of the government size on economic growth to become more important and relevant. This large expansion has also brought up the issue of whether the effect of government size on the growth is linear or not. The non-linear relationship between the government size and economic growth, illustrated as an inverted U shaped curve and called Armey curve popularised by Armey (1995). The arguments regarding non-linear relationship theoretically originated from an influential and important contribution of Barro (1990), who suggests that the effect of an increase in government spending and taxation on the economic growth depends on the size of the government, implying a positive (negative) net effect if the government size is small (big) in an endogenous growth model. This clearly indicates the existence of an optimal or growth maximizing level for government size.

\footnotetext{
* Pelin Varol Iyidogan, Department of Public Finance, Hacettepe University, Beytepe-Ankara, Turkey (pelinv@hacettepe.edu.tr);

Taner Turan, Department of Economics, Gebze Technical University, Gebze-Kocaeli, Turkey (turantaner01@yahoo.com).
} 
In essence, a certain level of government spending is needed to provide at least some essential public services, such as protecting the property rights and ensuring the public order and safety, for a well-functioning economic system. However, after some level, an increase in government size can inhibit the economic growth through different channels. As the government size gets larger, marginal returns or efficiencies of government provided services diminish. In addition, it is a standard assumption that the distortions arising from taxation rise more than proportionately with the increase in tax rates. To finance a large government size requires high tax rates, leading to an increasing detrimental effect on the economic activity. For instance, Prescott (2003) highlights the importance of higher tax rates to explain the difference in labour supply behaviour between some European countries and the US, implying a slower growth rate is associated with a big government size in the former compared to that of the latter. Moreover, many other reasons are put forward in explaining the possible negative effect of a large government size on the growth rate. For example, it is suggested that a large government size would be associated with a weak productivity growth and capital efficiency (Dar and AmirKhalkhali, 2002), a slow discovery and wealth creation process (Gwartney et al., 1998), an increasing volume of rent-seeking activities of special interest groups (Sheehey, 1993; Bergh and Henrekson, 2011; Christie, 2014).

We think that it is much more important for emerging economies to avoid wasting resources. In a sense, developed or rich countries could more easily afford or compensate to have a large government size than developing ones. As an emerging economy, it is crucial for Turkey to have an optimal government size and thus efficiently allocate its scarce resources between the public and private use in order to attain a high growth rate. This requires to estimate the optimal size of government, to compare it to actual size and implement some policy measures accordingly, if needed.

In the considered analysis period, Turkey has experienced 2001 financial and 2008 global crises that led to damaging adverse effects on the economy. Aftermath of 2001 crisis, the government imposed some austerity measures such as controlling public expenditures, which had risen unrestrainedly in the 1990s, to provide fiscal discipline in accordance with "Transition to Strong Economy Stability Programme". However, as a consequence of 2008 crisis triggered by the burst of housing bubble in US, economic growth decelerated in Turkey as in all economies hit by the global crisis. To boost economic growth, a fiscal stimulus package that embodies expansionary fiscal policy measures such as rise in the government investment expenditure, tax cuts and fiscal incentives has been implemented. Thus, taking into account the fluctuations in Turkish economy due to those crises and stability programmes, it is required to examine the government size-growth nexus in a non-linear framework and estimate threshold levels for government size (total, consumption, and investment expenditures), which are the major contributions of our study to the existing literature. Hereby, we also investigate the non-monotonicity of regarding relationship, in other words the negative/positive impact of government expenditure on economic growth in the cases of small or large government size. Our results clearly indicate that there exists a non-linear relationship, suggesting that after some threshold level, an increase in the government size has a negative and significant effect on growth rate.

The remainder of our paper is organised as follows: We review the literature in Section 2, present the data and model specification in Section 3, report and discuss the findings in Section 4, and conclude in Section 5. 


\section{Literature Review}

There is a vast literature trying to uncover the effect of government size on the economic growth. Some studies such as Guseh (1997), Fölster and Henrekson (2001), RomeroAvila and Strauch (2008), Roy (2009), Afonso and Fuceri (2010) find that the government size has a negative effect while other studies like Ram (1986), Ghali (1999), Günalp and Gür (2002), and Alexiou (2009), report a positive one. ${ }^{1}$ Sheehey (1993) concludes that the effect of a change in government size on growth depends on the relative size of government and the income level. Moreover, Kuştepeli (2005) finds that a relatively small (medium) sized government has a detrimental (positive) effect by using panel data for some European countries. However, the focus of these studies is not to estimate an optimal size for government, which is the main interest of the present paper.

Motivated by theoretical considerations and predicitons, many studies estimate the optimal or growth maximizing rate of government size by using different empirical models. To do so, some relatively early studies employ linear models, while many others prefer quadratic specifications. However, threshold regression and smooth regression models have been more popular and extensively used in recent years.

Karras (1996) develops a framework, based on Barro (1990), and used some later studies in the literature to examine the relationship between the government size and growth. He reports that the optimal amount of government consumption expenditures is $23( \pm 2)$, $14( \pm 4)$ and $33( \pm 6)$ per cent of GDP for average country, average OECD and South American country, respectively. In a similar way, Karras (1997) estimates the optimal government size to be $16( \pm 3)$ per cent for 20 European countries. In this strand of the literature, Aly and Strazicich (2000) conclude that the optimal government size is 9 per cent of GDP for 5 Gulf countries. Alleyne et al. (2004) estimate the optimal size of government is between 10 and 16 per cent, on average, for Caribbean countries, while Gunalp and Dinçer (2010) find the optimal government size to be 17.3 per cent $( \pm 3)$ for average transition country.

In order to estimate the optimal government size, a quadratic approach is utilized to investigate the non-linear relationship between the government size and growth in some studies. The square of government size included as an independent variable in these models to capture the effect of non-linearity. A significant and negative coefficient on the squared term confirms the existence of the non-linear impact of government size on economic growth. Table 1 presents a summary of these studies.

These studies conclude with a non-linear relationship between the government size and growth. As presented in Table 1, estimated optimal size, as expected, markedly differs among countries. It seems that the optimal size in European countries is larger than that of other countries. We would like to point out that the estimated optimal rate is in the range between 17 and 25 per cent in emerging economies, including Brazil, Nigeria, Turkey, Romania and Bulgaria. The optimal rate estimated by Chobanov and Mladenova (2009) is lower as it is related to government consumption expenditures not total expenditures. In our opinion, the sharp difference between the optimal rates for European countries could be attributed to the use of different time periods and proxies for government size.

1 For a more comprehensive survey see Facchini and Melki (2013). 
Table 1 | A Summary of Studies Estimating a Quadratic Model

\begin{tabular}{|c|c|c|c|}
\hline Study & Sample Country & Sample Period & $\begin{array}{l}\text { Estimated optimal } \\
\text { size (as \% of GDP) }\end{array}$ \\
\hline \multirow{6}{*}{$\begin{array}{l}\text { Vedder and Gallaway } \\
\text { (1998) }\end{array}$} & US & 1947-1997 & 17.45 \\
\hline & Canada & 1926-1988 & 21.37 \\
\hline & Denmark & $1854-1988$ & 26.14 \\
\hline & Italy & 1862-1988 & 22.23 \\
\hline & Sweden & 1881-1988 & 19.43 \\
\hline & UK & 1830-1988 & 20.97 \\
\hline Pevcin (2005) & $\begin{array}{l}12 \text { European } \\
\text { countries }\end{array}$ & 1951-1995 & $36.56,40.30,42.12$ \\
\hline Mavrov (2007) & Bulgaria & 1990-2004 & 21.42 \\
\hline $\begin{array}{l}\text { Chobanov and } \\
\text { Mladenova (2009) }\end{array}$ & 81 countries & 1961-2005 & 10.80 \\
\hline \multirow{2}{*}{ Mutaşcu and Miloş (2009) } & Old EU members & \multirow{2}{*}{ 1999-2008 } & 30.42 \\
\hline & New EU members & & 27.46 \\
\hline \multirow{12}{*}{$\begin{array}{l}\text { Forte and Magazzino } \\
(2010)\end{array}$} & Austria & \multirow{12}{*}{ 1970-2009 } & 38.21 \\
\hline & Belgium & & 35.39 \\
\hline & Denmark & & 38.63 \\
\hline & Finland & & 40.38 \\
\hline & France & & 39.49 \\
\hline & Germany & & 41.99 \\
\hline & Greece & & 39.33 \\
\hline & Irland & & 44.47 \\
\hline & Italy & & 37.68 \\
\hline & PBS & & 35.52 \\
\hline & Portugal & & 42.28 \\
\hline & UK & & 43.50 \\
\hline Herath (2012) & Sri Lanka & 1959-2009 & 27.00 \\
\hline \multirow{3}{*}{ Altunc and Aydın (2013) } & Turkey & \multirow{3}{*}{$1995-2011$} & 25.21 \\
\hline & Romania & & 20.44 \\
\hline & Bulgaria & & 22.45 \\
\hline Facchini and Melki (2013) & France & $1896-2008$ & 30.00 \\
\hline Hok et al. (2014) & 8 ASEAN countries & $1995-2011$ & 28.50 \\
\hline Alimi (2014) & Nigeria & 1970-2012 & 19.81 \\
\hline Turan (2014) & Turkey & $1970-2012$ & 17.00 \\
\hline $\begin{array}{l}\text { Mendonça and Cacicedo } \\
\text { (2015) }\end{array}$ & Brazil & 2000:1-2013:3 & 22.00 \\
\hline
\end{tabular}


Table 2 | A Summary of Studies Using a Threshold or Smooth Transition Model

\begin{tabular}{|c|c|c|c|}
\hline Study & Sample Country & Sample Period & $\begin{array}{c}\text { Estimated } \\
\text { threshold } \\
\text { level (as \% of GDP) }\end{array}$ \\
\hline \multirow{3}{*}{ Chen and Lee (2005) } & \multirow{3}{*}{ Taiwan } & \multirow{3}{*}{ 1979:1-2003:3 } & $22.84^{*}$ \\
\hline & & & $14.97^{* *}$ \\
\hline & & & $7.30^{* * *}$ \\
\hline \multirow{3}{*}{$\begin{array}{l}\text { Abounoorie and Nademi } \\
(2010)\end{array}$} & \multirow{3}{*}{ Iran } & \multirow{3}{*}{ 1959-2006 } & $34.70^{*}$ \\
\hline & & & $23.60^{* *}$ \\
\hline & & & $8.00^{* * *}$ \\
\hline \multirow{8}{*}{ Samimi et al. (2010) } & Iran & \multirow{8}{*}{$1980-2007$} & $24.60^{* *}$ \\
\hline & Pakistan & & $11.90^{* *}$ \\
\hline & Turkey & & $13.96 * *$ \\
\hline & Egypt & & $16.53^{* *}$ \\
\hline & Algeria & & $16.54^{* *}$ \\
\hline & Indonesia & & $7.00^{* *}$ \\
\hline & Oman & & $26.11 * *$ \\
\hline & Jordan & & $26.09 * *$ \\
\hline \multirow{5}{*}{ Chiou-Wei et al. (2010) } & South Korea & \multirow{5}{*}{$1961-2004$} & $11.00^{* *}$ \\
\hline & Malaysia & & n.a. \\
\hline & Singapore & & $11.00^{* *}$ \\
\hline & Thailand & & $16.00^{* *}$ \\
\hline & Taiwan & & $11.00^{* *}$ \\
\hline \multirow{2}{*}{ Vaziri et al. (2011) } & Iran & \multirow{2}{*}{$1960-2007$} & $25.00^{* *}$ \\
\hline & Pakistan & & $12.00 * *$ \\
\hline $\begin{array}{l}\text { Mehdi and Shoorekchali } \\
\text { (2012) }\end{array}$ & Italy & 1960-2009 & $20.61^{* *}$ \\
\hline \multirow[b]{2}{*}{ Hajamani and Falahi (2014) } & 21 Low income count. & \multirow[b]{2}{*}{$1981-2007$} & $16.20^{* *}$ \\
\hline & $\begin{array}{l}11 \text { Low-Middle } \\
\text { income countries }\end{array}$ & & $16.90^{* *}$ \\
\hline Christie (2014) & Panel of 136 countries & $1971-2005$ & $33.00^{*}$ \\
\hline Thanh and Hoai (2014) & ASEAN countries & $1980-2011$ & $25.69 * *$ \\
\hline \multirow{3}{*}{$\begin{array}{l}\text { Asimakopoulos and } \\
\text { Karavias (2015) }\end{array}$} & Panel of 129 countries & \multirow{3}{*}{$1980-2009$} & $18.04^{* *}$ \\
\hline & Developing Countries & & $17.96^{* *}$ \\
\hline & Developed Countries & & $19.12^{* *}$ \\
\hline
\end{tabular}

Note: ${ }^{*},{ }^{*}, * * *$ indicate the government total, consumption, and investment expenditure, respectively. n.a. not available

Source: Authors. 
In recent years, an increasing number of studies adopt a different approach to test the non-linear relationship by means of threshold regression or smooth transition regression models. In this context, the study of Chen and Lee (2005), modifying the growth model suggested by Ram (1986), is the first using the threshold regression approach. This stream of the literature tries to uncover as to whether the non-linear model performs better or not and to estimate the threshold value that is the turning or changing point in the relation. We summarize these studies in Table 2.

In general, these studies report a non-linear relationship, implying the effect of government size on growth turns to be a negative one if it exceeds the estimated threshold level. When the government consumption share is the threshold variable, estimated threshold level falls into the 15 to 20 per cent range for many countries. Moreover, the estimates of Asimakopoulos and Karavias (2015) clearly indicate that the threshold levels are very similar for developing and developed countries. This is also the case for the results reported by Hajamani and Falahi (2014) for low and low-middle income countries. However, Thanh and Hoai (2014) highlight that their results greatly differ from that of Chiou-Wei et al. (2010). On the other hand, it would not be appropriate to compare the results of different studies, due to the use of different samples and estimation methods.

\section{Data and Model Specification}

We examine the existence of Armey curve for Turkish economy over the period 1998Q12015Q1. The description and source of seasonally adjusted data which is obtained from the Central Bank of the Republic of Turkey are summarized in Table 3.

Table 3 | Data: Definition and Source

\begin{tabular}{|l|l|}
\hline Variables & Definition \\
\hline $\boldsymbol{Y}$ & GDP growth rate \\
\hline $\boldsymbol{C} / \boldsymbol{G}$ & Government consumption expenditure (\% of GDP) \\
\hline $\mathbf{G I} \boldsymbol{Y}$ & Government sector gross fixed capital formation (\% of GDP) \\
\hline $\mathbf{G} / \boldsymbol{Y}$ & Total government expenditure (\% of GDP) \\
\hline $\mathbf{G O V}$ & $\begin{array}{l}\text { The product of government expenditure growth and government size (government } \\
\text { expenditure /GDP) }\end{array}$ \\
\hline $\boldsymbol{I} \boldsymbol{Y}$ & Private sector gross fixed capital formation (\% of GDP) \\
\hline
\end{tabular}

We employ the model of Ram (1986) following Chen and Lee $(2005)^{2}$ to analyse the non-linear relationship between government size and economic growth. The model derives from the production functions of government and non-government sectors and finally takes the form as following regression:

2 Unlike the model of Chen and Lee (2005), we do not use growth of labour force as a control variable since the available data for regarding series is not sufficient to estimate regressions through splitted samples. However, we obtain very similar results when the labour force growth is added to the model for the period 2006:1-2015:1, in which the data on the growth of labour force is available. These results are available upon request. 


$$
y_{t}=\alpha_{0}+\alpha_{1}\left(I_{t} / Y_{t}\right)+\alpha_{2} G O V_{t}+u_{t}
$$

where GDP growth rate is determined by investment rate and growth of government expenditure multiplied by government size, respectively. The $\alpha_{2}$ coefficient implying the multiple effect of government sector on economic growth arises from two sources. The first one is the direct impact of government and the other is the externality effect, that is the indirect contribution of government via non-government sector.

To examine the validity of Armey curve for Turkish economy through Equation 1, we use the threshold specification of Hansen $(1996,2000)$ as follows:

$$
y_{t}=\alpha X_{t}+ \begin{cases}\beta_{1} G O V_{t}+e_{1 t}, & q_{t} \leq \gamma \\ \beta_{2} G O V_{t}+e_{2 t}, & q_{t}>\gamma\end{cases}
$$

Here, $y_{t}$ is the dependent variable, in other words economic growth, $X_{t}$ is the vector of independent variables $\left(I_{t} / Y_{t}\right)$ in Equation 1 with the exception of $G O V_{t}, q_{t}$ is the threshold variable which splits the sample into two regimes. In our study, we use 3 different threshold variables, which are government consumption expenditure, government investment expenditure and total government expenditure to divide the observations.

This methodology allows to examine differentiating effects of government size on economic growth in lower and upper regimes depending on whether the threshold variable is smaller or higher than threshold value, $\gamma$. Coefficients $\beta_{1}$ and $\beta_{2}$ indicate the considered effect in lower and higher regimes, respectively. First, optimum threshold $(\hat{\gamma})$ is determined as the value which minimizes the residual sum of squares across all possible values of $\gamma$ experimented in estimation of Equation 1. Once $\hat{\gamma}$ is determined, slope parameters are estimated as $\hat{\alpha}(\hat{\gamma})$ and $\hat{\beta}(\hat{\gamma})$. Then, to test the statistical significance of $\gamma$, that is the existence of threshold effect, Hansen (1996) uses heteroskedasticityconsistent Lagrange multiplier test which computes asymptotically correct p-values through bootstrap to overcome the identification problem of $\gamma$ under the null of linearity (no threshold).

\section{Empirical Results}

Using 1000 bootstrap replications and $10 \%$ trimming percentage, we find that threshold effect which splits sample exists for all three threshold variables as presented in Table 4, 5 and 6. More briefly, LM test for no threshold rejects the null hypothesis of linearity.

As Table 4 indicates, we find evidence of Armey curve in the case that government consumption expenditure/GDP is chosen as threshold variable. In the lower regime where the government size is below or equal to $12.6 \%$, government size has a positive impact on economic growth while an inverse relationship exists in the higher regime with a large government size.

When the government investment expenditure/GDP is the threshold variable, government size contributes positively to economic growth in the linear model. However, when we consider non-linearity, the regarding relation alters among two regimes. Government investment expenditure exceeding the threshold (3.9\%) leads to an economic slowdown contrary to lower regime (Table 5). 
Table 4 | Linear and Non-Linear Effects of Government Consumption Expenditure on Economic Growth

\begin{tabular}{|l|c|c|c|}
\hline & Linear Model & $\begin{array}{c}\text { Regime 1: Small } \\
\text { government size }\end{array}$ & $\begin{array}{c}\text { Regime 2: Large } \\
\text { government size }\end{array}$ \\
\hline Threshold variable: $C / Y$ & - & $C / Y \leq 0.126$ & $C / Y>0.126$ \\
\hline Intercept & $0.036(0.92)$ & $0.089^{* * *}(2.23)$ & $0.054^{* * *}(1.81)$ \\
\hline GOV & $2.756^{*}(6.41)$ & $3.064^{*}(10.94)$ & $-1.619^{*}(5.58)$ \\
\hline I/Y & $0.082^{* *}(3.37)$ & $0.299^{* *}(4.32)$ & $0.251^{* *}(3.48)$ \\
\hline LM test for no threshold & 23.360 & Bootstrap p-value & 0.031 \\
\hline Number of observations & 69 & 33 & 36 \\
\hline
\end{tabular}

Note: Values in parenthesis indicate t-values. ${ }^{*},{ }^{* *},{ }^{* * *}$ denote significance at $1 \%, 5 \%$ and $10 \%$ levels. Source: Authors estimations.

Table 5 | Linear and Non-Linear Effects of Government Investment Expenditure on Economic Growth

\begin{tabular}{|l|c|c|c|}
\hline & Linear Model & $\begin{array}{c}\text { Regime 1: Small } \\
\text { government size }\end{array}$ & $\begin{array}{c}\text { Regime 2: Large } \\
\text { government size }\end{array}$ \\
\hline Threshold variable: GI/Y & - & $G I / Y \leq 0.039$ & $G I / Y>0.039$ \\
\hline Intercept & $0.108^{* *}(2.76)$ & $0.043(1.43)$ & $0.196^{* * *}(2.17)$ \\
\hline GOV & $4.125^{* *}(3.44)$ & $5.807^{*}(4.72)$ & $-2.754^{* *}(3.06)$ \\
\hline I/Y & $0.469^{* *}(2.88)$ & $0.167^{* *}(2.53)$ & $0.895^{* *}(2.42)$ \\
\hline LM test for no threshold & 45.710 & Bootstrap p-value & 0.018 \\
\hline Number of observations & 69 & 43 & 26 \\
\hline
\end{tabular}

Note: Values in parenthesis indicate t-values. ${ }^{*}, * * * * *$ denote significance at $1 \%, 5 \%$ and $10 \%$ levels. Source: Authors estimations.

Table 6 | Linear and Non-Linear Effects of Total Government Expenditure on Economic Growth

\begin{tabular}{|l|c|c|c|}
\hline & Linear Model & $\begin{array}{c}\text { Regime 1: Small } \\
\text { government size }\end{array}$ & $\begin{array}{c}\text { Regime 2: Large } \\
\text { government size }\end{array}$ \\
\hline Threshold variable: G/Y & - & $G / Y \leq 0.165$ & $G / Y>0.165$ \\
\hline Intercept & $0.046(1.53)$ & $0.106^{* *}(2.12)$ & $0.081^{* *}(2.72)$ \\
\hline GOV & $2.419^{*}(9.30)$ & $2.298^{*}(7.66)$ & $-1.957^{*}(6.52)$ \\
\hline I/Y & $0.19(1.23)$ & $0.440^{* * *}(2.47)$ & $0.460(1.19)$ \\
\hline LM test for no threshold & 18.740 & Bootstrap p-value & 0.087 \\
\hline Number of observations & 69 & 32 & 37 \\
\hline
\end{tabular}

Note: Values in parenthesis indicate t-values. ${ }^{*},{ }^{* *},{ }^{* * *}$ denote significance at $1 \%, 5 \%$ and $10 \%$ levels. Source: Authors estimations. 
Table 6 presents that in the model where total government expenditure/GDP is the threshold variable, non-linear nexus exists between the government size and economic growth. Total government expenditure above $16.5 \%$ stimulates growth as in the linear model while vice versa in the upper regime with a large government size. Moreover, in all 3 models with different threshold variables, the private investment ratio raises economic growth with the exception of linear model and upper regime of model in Table 4 utilizing the total government expenditure as the threshold variable.

Our results regarding the government consumption expenditures are especially in line with that of Samimi et al. (2010) for Turkey, Chiou-Wei et al. (2010) for South Korea, Singapore and Taiwan and Chen and Lee (2005) for Taiwan. As for government total expenditures, our estimated threshold level is lower compared to that of Christie (2014) for 136 countries, Altunc and Aydin (2013) for Turkey, and Chen and Lee (2005) as well, but consistent with result of Turan (2014) even though different measures for government size, time periods and methods are employed. We also find a much lower threshold level for the government investment expenditure than reported by Chen and Lee (2005) for Taiwan and Abounoorie and Nademi (2010) for Iran.

It seems that, in Turkey, the actual government consumption expenditures, as a share of GDP, have been well above the estimated threshold level for a long time. For example, the consumption expenditure is 15.3 per cent in 2014 . We should note that after 2009 there exists a significant increase in the consumption expenditures. Although the actual investment expenditure is higher than the threshold level in 2013 and 2014, it is below the threshold level during 2003-2009 period, in which an IMF supported stabilization programme was in effect. Finally, realized total expenditures have been greater than the threshold level for many years, mainly as a result of the expansion of consumption expenditures.

\section{Conclusion}

We investigate the relationship between the government size and economic growth for Turkey by using threshold regression model and quarterly data over the period 1998:1-2015:1. Our findings strongly indicate that there exists a non-linear relationship in the case of Turkey and confirm the validity of Armey curve. The estimated threshold levels, as shares of GDP, are 16.5 per cent for the government total expenditures, 12.6 per cent for consumption expenditures and 3.9 per cent for investment expenditures. We find that an increase in the government size leads to a significant rise (decline) in the economic growth rate when the government size is below (above) the threshold level, suggesting a nonmonotonic relationship.

Due to a large expansion of the consumption expenditures, the government size has considerably increased in Turkey during the period examined. The realized consumption and total government expenditures have been well above the estimated threshold levels for a long time. Although actual investment expenditure is higher than the threshold level in recent years, it is below the threshold level over the period 2003-2009 in which an IMF supported stabilization programme implemented. We think that this interesting point deserves a thorough treatment in a future study.

Our findings have obviously some policy implications. We present a strong evidence for the claim that a large government size does not necessarily lead to a higher growth rate. On the contrary, after some threshold level, an increase in the government size has a significant negative or detrimental effect. Nevertheless, actual government size is larger 
than the estimated optimal ones in most countries with a high share of unproductive spending. This implies that the growth rate may not be the most important target or concern for policy makers in determining the government size. However, it should be kept in mind that a lower growth rate than possible or attainable one has undoubtedly some costs. Although, at least in theory, the final decision on the government spending is and should be made by the public in democratic societies, we tend to think that it would be better to focus on making government spending more efficient and restraining especially the unproductive spending in order to boost the economic growth.

Moreover, for a more detailed discussion of policy implications, the potential burdens such as ageing population problem on government budget should also be considered. As United Nations (2013) projects, globally the number of older persons is expected to more than double, from 841 million people in 2013 to about 2 billion in 2050 . Thus, the governments should impose proper policy reforms to overcome the economic and social outcomes of ageing population trend. In this regard; Prescott (2003) points out that in the existence of high labour supply elasticity, the pay as you go system in which current old retirees are financed by the contribution of young workers collapses as a consequence of increasing tax rates. Instead, reducing the effective marginal tax rate on labour and restructuring the retirement systems would be a more optimal policy combination. From the view point of our study, in the absence of this kind of policy reforms in Turkey, ageing population problem would have several implications for the future size of government with regard to increasing public health and social security expenditures.

\section{References}

Abounoori, E., Nademi, Y. (2010). Government Size Threshold and Economic Growth in Iran. International Journal of Business and Development Studies, 2(1), 95-108.

Afonso, A., Fuceri, D. (2010). Government Size, Composition, Volatility and Economic Growth. European Journal of Political Economy, 26(4), 517-532, http://dx.doi.org/10.1016/j. ejpoleco.2010-02-002

Alexiou, C. (2012). Government Spending and Economic Growth: Econometric Evidence from the South Eastern Europe (SEE). Journal of Economic and Social Research, 11(1), 1-16. Available at: http://jesr.journal.fatih.edu.tr/jesr.alexiou.pdf

Alimi, R. S. (2014). Does Optimal Government Size Exists for Developing Economies? The Case of Nigeria. MPRA Paper No. 56073.

Alleyne, K-A., Lewis-Bynoe, D., Moore, W. (2004). An Assessment of the Growth-Enhancing Growth Size of Government in the Caribbean. Applied Econometrics and International Development, 4(3), 77-94. Available at: http://www.usc.es/economet/journals1/aeid/aeid435.pdf

Altunc, O. F., Aydın C. (2013). The Relationship between Optimal Size of Government and Economic Growth: Empricial Evidence from Turkey, Romania and Bulgaria. ProcediaSocial and Behavioral Sciences, 92, 66-75, http://dx.doi.org/10.1016/j.sbspro.2013.08.639

Aly, H., Strazicich, M. (2000). Is the Government Size Optimal in the Gulf Countries of Middle East? An Empirical Investigation. International Review of Applied Economics, 14(4), 475-483, http://dx.doi.org/10.1080/02692170050150147

Armey, D. (1995). The Freedom Revolution. Washington: Regnery Publishing.

Asimakopoulos, S., Karavias, Y. (2015). The Impact of Government Size on Economic Growth: A Threshold Analysis. Granger Centre Discussion Paper No. 15/02. 
Barro, R. J. (1990). Government Spending in a Simple Model of Endogeneous Growth. Journal of Political Economy, 98(5), 103-125, http://dx.doi.org/10.1086/261726

Barro, R. J., Sala-i-Martin, X. (1992). Public Finance in Models of Economic Growth. The Review of Economic Studies, 59(4), 645-661, http://dx.doi.org/10.2307/2297991

Bergh, A., Henrekson, M. (2011). Government Size and Growth: A Survey and Interpretation of the Evidence. Journal of Economic Surveys, 25(5), 872-897, http://dx.doi.org/10.1111/ j.1467-6419.2011.00697.x

Chen, S. T., Lee, C. C. (2005). Government Size and Economic Growth in Taiwan: A Threshold Regression Approach. Journal of Policy Modeling, 27(9), 1051-1066, http://dx.doi.org/10.1016/j.jpolmod.2005.06.006

Chobanov, D., Mladenova, A. (2009). What is the Optimum Size of Government? Institute for Market Economics, Bulgaria. Available at: http://ime.bg/uploads/335309_ OptimalSizeOfGovernment.pdf

Chiou-Wei, S-Z., Zhu, Z., Kuo, Y-H. (2010). Government Size and Economic Growth: An Application of the Smooth Regression Regression Model. Applied Economics Letters, 17(14), 1405-1415, http://dx.doi.org/10.1080/13504850902984295

Christie, T. (2014). The Effect of Government Spending on Economic Growth: Testing the NonLinear Hypothesis. Bulletin of Economic Research, 66(2), 183-204, http://dx.doi.org/10.1111/ j.1467-8586.2012.00438.x

Dar, A. A., Amirkhalkhali, S. (2002). Government Size, Factor Accumulation, and Economic Growth: Evidence from OECD Countries. Journal of Policy Modeling, 24(7-8), 679-692, http://dx.doi.org/10.1016/S0161-8938(02)00163-1

Facchini, F., Melki, M. (2013). Efficient Government Size: France in the 20th Century. European Journal of Political Economy, 31, 1-14, http://dx.doi.org/10.1016/j.ejpoleco.2013.03.002

Forte, F., Magazzino, C. (2010). Optimal Size of Government and Economic Growth in EU-27. CREI Working Paper No. 4/2010.

Fölster, S., Henrekson, M. (2001). Growth Effects of Government Expenditure and Taxation in Rich Countries. European Economic Review, 45(8), 1501-1520, http://dx.doi.org/10.1016/S00142921(00)00083-0

Ghali, K. H. (1999). Government Size and Economic Growth: Evidence from a Multivariate Cointegration Analysis. Applied Economics, 31 (8), 975-987, http://dx.doi. org/10.1080/000368499323698

Günalp, B., Dinçer, O. (2010). The Optimal Government Size in Transition Countries, in Tavizde, A., ed., Progress in Economics Research. New York: Nova Science Publishers, 15, pp. 153-169.

Günalp, B., Gür, T. (2002). Government Expenditures and Economic Growth in Developing Countries: Evidence from a Panel Data Analysis. METU Studies in Development, 29(3-4), 311-332. Available at: http://www.acarindex.com/dosyalar/makale/ acarindex-1423910098.pdf

Guseh, J. H. (1997). Government Size and Economic Growth in Developing Countries: A Political-Economy Framework. Journal of Macroeconomics, 19(1), 175-192, http://dx.doi.org/10.1016/S0164-0704(97)00010-4

Gwartney, J., Lawson, R., Holcombe, R. (1998). The Size and Functions of Government and Economic Growth. Paper prepared for the Joint Economic Committee, Washington.

Hajamani, M., Falahi, M. A. (2014). The Nonlinear Impact of Government Consumption Expenditure on Growth: Evidence from Low and Low-Middle Income Countries. Cogent Economics \& Finance, 2, 1-15, http://dx.doi.org/10.1080/23322039.2014-948122 
Hansen, B. E. (1996). Inference When a Nuisance Parameter Is Not Identified under the Null Hypothesis. Econometrica, 64(2), 413-430, http://dx.doi.org/10.2307/2171789

Hansen, B. E. (2000). Sample Splitting and Threshold Estimation. Econometrica, 68(3), 575-603, http://dx.doi.org/10.1111/1468-0262.00124

Herath, S. (2012). Size of Government and Economic Growth: A Nonlinear Analysis. Economic Annals, 57(194), 7-30, http://dx.doi.org/10.2298/eka1294007h

Hok, L., Jariyapan, P., Buddhawongsa, P., Tansuchat, R. (2014). Optimal Size of Government Spending: Empirical Evidence from Eight Countries in Southeast Asia. The Empirical Econometrics and Quantitative Economics Letters, 3(4), 31-44. Abvailable at: http://www.jyoungeconomist.com/images/stories/EEQEL_V3_N4_pp_31_44_Hok_etal.pdf

Karras, G. (1997). On the Optimal Government Size in Europe:Theory and Empirical Evidence. The Manchester School, 65(3), 280-294, http://dx.doi.org/10.1111/1467-9957.00057

Karras, G. (1996). The Optimal Government Size Further International Evidence on the Productivity of Government Services. Economic Inquiry, 34(2), 193-203, http://dx.doi.org/10.1111/j.1465-7295.1996.tb01372.x

King, R., Rebelo, S. (1990). Public Policy and Economic Growth: Developing Neoclassical Economic Implications. Journal of Political Economy, 98(5), 126-150, http://dx.doi.org/10.1086/261727

Kuştepeli, Y. (2005). The Relationship between Government Size and Economic Growth: Evidence from a Panel Data Analysis. Dokuz Eylül University, Faculty of Business, Department of Economics, Discussion Paper Series No. 05/06.

Mavrov, H. (2007). The Size of Government Expenditure and the Rate of Economic Growth in Bulgaria. Economic Alternatives, 1, 53-63.

Mehdi, S., Shoorekchali, M. J. (2012). The Impact of Government Size on Economic Growth: A Case Study in Italy. Australian Journal of Basic and Applied Sciences, 6(9), 616-621. Available at: http://www.thebrokenwindow.net/papers/6/616-621.pdf

Mendonça, H. F., Cacicedo, T. (2015). Size of Government and Economic Growth in the Largest Latin American Country. Applied Economics Letters, 22(11), 904-910, http://dx.doi. org/10.1080/13504851.2014-987909

Mutaşcu, M., Miloş, M. (2009). Optimal Size of Government Spending. The Case of European Union Member States. Annales Universitatis Apulensis Series Oeconomica, 11(1), 447-456. Available at: http://www.oeconomica.uab.ro/upload/lucrari/1120091/45.pdf

Pevcin, P. (2005). Government and Economic Performance. Paper presented at the Sixth International Conference on Enterprise in Transition: International Conference Proceedings, pp. 1291-1300.

Prescott, E. C. (2003). Why Do Americans Work So Much More Than Europeans? Federal Reserve Bank of Minneapolis, Research Department Staff Report No. 321.

Ram, R. (1986). Government Size and Economic Growth: A New Framework and Some Evidence from Cross-Section and Time-Series Data. American Economic Review, 76(1), 191-203.

Romero-Avila, D., Strauch, R. (2008). Public Finances and Long Term Growth in Europe: Evidence from a Panel Data Analysis. European Journal of Political Economy, 24(1), 172-191, http://dx.doi.org/10.1016/j.ejpoleco.2007-06-008

Roy, A. G. (2009). Evidence on Economic Growth and Government Size. Applied Economics, 41(5), 607-614, http://dx.doi.org/10.1080/00036840601007393

Samimi, A. J., Nademi, Y., Zobeiri, H. (2010). Government Size \& Economic Growth: A Threshold Regression Approach in Selected Islamic Countries. Australian Journal of Basic and Applied Sciences, 4(8), 2247-2249. 
Sheehey, E. J. (1993). The Effect of Government Size on Economic Growth. Eastern Economic Journal, 19(3), 321-328. Available at: http://econpapers.repec.org/article/eejeeconj/ v_3a19_3ay_3a1993_3ai_3a3_3ap_3a321-328.htm

Solow, R. M. (1956). A Contribution to the Theory of Economic Growth. The Quarterley Journal of Economics, 70(1), 65-94, http://dx.doi.org/10.2307/1884513

Thanh, S. D., Hoai, B. T. M. (2014). The Threshold of Government Size and Economic Growth for ASEAN Countries: An analysis of the smooth transition regression model. Mimeo. Available at: http://papers.ssrn.com/sol3/papers.cfm?abstract_id=2493744

Turan, T. (2014). Optimal Size of Government in Turkey. International Journal of Economics and Financial Issues, 4(2), 286-294. Available at: http://www.econjournals.com/index.php/ ijefi/article/viewFile/717/pdf

United Nations (2013). World Population Ageing 2013 Report. Department of Economic and Social Affairs Population Division, New York.

Vaziri, H., Nademi, Y., Paghe, A., Nademi, A. (2011). Does Armey Curve Exist in Pakistan and Iran Economies? Journal of Applied Sciences Research, 7(5), 562-565.

Vedder, R. K., Gallaway, L. E. (1998). Government Size and Economic Growth. Paper prepared for the Joint Economic Committee, Washington. 